„,Cobb-Douglas production function Revisited, VAR and VECM Analysis and a Note on Fisher/Cobb-Douglass Paradox” e објавен во следните меѓународни џурнали:Macroeconomics: Production\& Investment eJournal, Vol.4,No.42:, Sep 26, 2011,Macroeconomics:Aggregative models eJournal Vol.4,No.78:Sep 26,2011,Economic Growith eJournal Vol.3,No.111:Sep 30,2011 .

\title{
Cobb-Douglas production function revisited, VAR and VECM analysis and a note on Fischer/Cobb-Douglass paradox
}

Dushko Josheski (dushkojosheski@gmail.com)

Darko_Lazarov (darko.lazarov@ugd.edu.mk)

Cane Koteski (cane.koteski@ugd.edu.mk)

\begin{abstract}
Cobb-Douglas production function is a basic function in growth models. The modeling in this paper showed that VAR is stable; KPSS test showed that output, capital and labor are not trend stationary. Johansen's co-integration test showed that a requirement for Fischer/CobbDouglass paradox to work is met at 3 lags, there factor shares are I(0). The Fisher/CobbDouglas Paradox is based on constant factor shares. (In terms of time-series analysis, such constancy is equivalent to factor shares being I(0). The Fisher/Cobb-Douglas Paradox is thus why the estimated $\sigma$ equals unity independent of the underlying production technologies generating the simulated data.At 4 lags however these variables are I(1) variables i.e. CobbDouglass is not CES function anymore. ADF test for factors of production showed that natural logarithm of capital is stationary variable, while log of labor is not-stationary except at $10 \%$ level of significance. Adjustment parameters showed that labour responds more / faster than loutput (log of GDP) and lcapital on if there is change / shock in the system.VECM model failed the stability eingevalues test.
\end{abstract}

Key words: Fisher/Cobb-Douglas Paradox,cointegration, VAR,VECM,ADF test , unit root, 


\section{Literature review of Neoclassical production function}

The process of economic growth depends on the shape of the production function. The production function represents a mathematical equation that shows the combinations of production factors (capital and labor) necessary to produce a certain amount of output.

In addition, we will interpret the production function. We say that the production function, $F(K, L, T)$, is neoclassical, if the following conditions are met:

1. Constant returns of scale. The function has constant returns of scale when the rise of capital and labor for a positive constant $\lambda$, will contribute to increasing output of $\lambda$.

$$
F(\lambda K, \lambda L, A)=\lambda \cdot F(K, L, A) \text { за сите } \lambda>0
$$

Simplified, the property of constant returns of scale shows that the dual increasing of the factors of productions (capital and labor) causes a doubling of output.

\section{Characteristics of diminishing marginal product of production factors (labor and capital).}

The value of the first derivative of the production function is positive, indicating that the marginal product of capital is a positive value. The increase of capital causes the increase of total output.

$$
f^{\prime}(k)=A a k^{\alpha-1}>0
$$

The value of the second derivative of the production function is negative, indicating that the marginal product tents to decrease. The characteristic of the declining marginal product of capital shows that the additional deployment of capital contributes to increasing the total output, but the dynamic of increase of total output is less than the dynamic of increase of capital with any additional capital increase. The same feature of declining 
marginal product of labor needs to apply as a factor of production. But here is very important to note that the property of decreasing marginal product is valid provided that technology and other factors of production do not change, remaining constant over time.

$$
f^{\prime \prime}(k)=-A a(1-a) k^{\alpha-2}<0
$$

The characteristic of decreasing marginal productivity of capital ${ }^{1}$ is important because: First, it limits the ability of the model of Solow and Swan give adequate explanation for the difference in the level of per capita income between countries and, secondly, it limits the ability to give a full explanations of the differences in the rate of economic growth.

These are important features that differentiate the traditional view of economic growth (exogenous growth theory) of the new generation of models of growth, endogenous growth models.

3. Inada condition. The third feature of the neoclassical production function is the Inada condition, which can be mathematically introduced by the following equation:

$$
\begin{array}{lll}
\lim _{K \rightarrow+\infty} \frac{d Y}{d K}=0 & \text { и } & \lim \frac{d Y}{d K}=+\infty \\
& K \rightarrow 0
\end{array}
$$

The first expression shows that the marginal product of capital approaches zero, if capital moves towards infinity, while the second term shows that the marginal product of capitals moves towards infinity, if capital is approaching zero.

\section{Cobb-Douglas production function}

One of the most common used production functions by economists is Cobb-Douglas production function. It represents a simple production function that gives a responsible description of actual economies.

\footnotetext{
${ }^{1}$ Basic indicators of marginal productivity are: marginal product (MPK) and the capital value of marginal product of capital (VMPK).
} 
Cobb-Douglas production function can be written as:

$$
\begin{aligned}
Y(t) & =F[K(t), L(t), A(t)] \\
& =A K^{\alpha} L^{1-\alpha} \quad \text { equation }
\end{aligned}
$$

where, $A>0$, and it shows the level of technology and, $\alpha$, is a number between 0 and 1 . Often it is assumed that the exponent $\alpha$ is $1 / 3$, that means $K$ in creation of $Y$ participate with $1 / 3 .^{2}$

The production function of the equation (1.10) we can write in the form of output per worker (output per worker), so that both sides of equation (1.10) we will divide by $L$ :

$$
\frac{Y}{L}=A\left(\frac{K}{L}\right)^{\alpha}
$$

Where, if we change for: $Y / L=y$ и за $K / L=k$, will get the following so-called intensive form of production function:

$$
y=A k^{\alpha}
$$

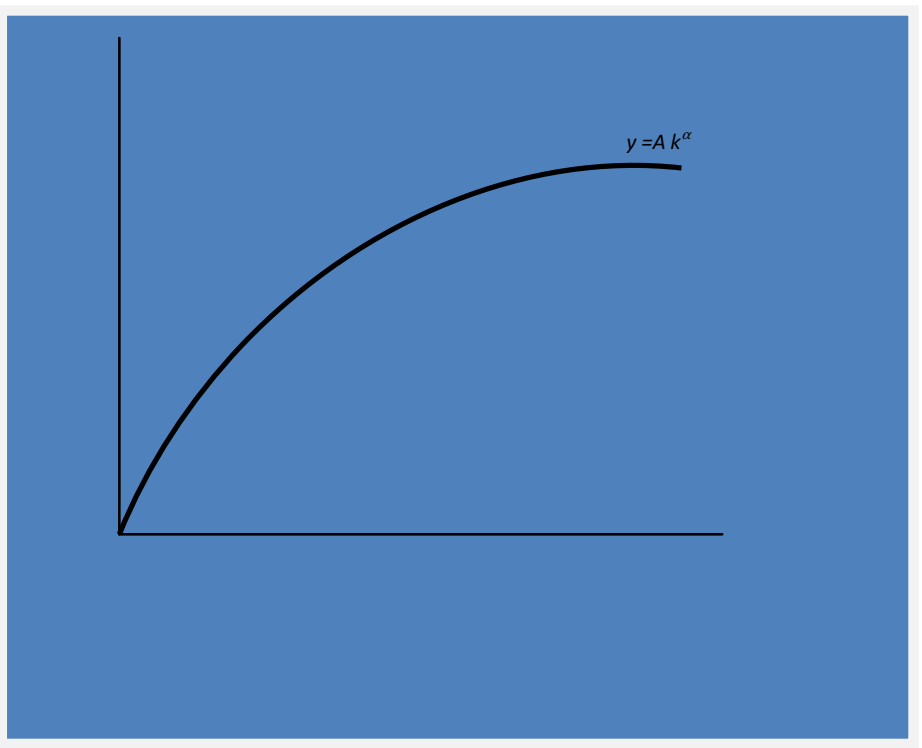

${ }^{2}$ In the original production function of the Paul H. Douglas and Charles W. Cobb, $\alpha=1 / 4$ 
Cobb-Douglas function meets the conditions to be treated as neoclassical production function. The characteristic of the positive and declining marginal product of capital: $f^{\prime}(k)=A a k^{\alpha-1}>0 \quad, f^{\prime \prime}(k)=-A a(1-a) k^{\alpha-2}<0$ and, Inada condition: $\lim _{k \rightarrow \infty} f^{\prime}(k)=0$ $\lim _{k \rightarrow 0} f^{\prime \prime}(k)=\infty$.

Cobb-Douglas production function provides an opportunity to establish the participation of certain factors of productions (labor and capital) in creating the total output (income) in the economy. In a market economy, factors of production, labor and capital, are paid according to their marginal product. Thus, the marginal product of capital is equal to its cost districts $R$, and the marginal product of labor equals the wage, as rental income from renting labor. This we can show mathematically using the following equations:

$$
R=f^{\prime}(k)=A a k^{\alpha-1}
$$

Where, the amount of unit capital is paid according to his marginal product, and:

$$
\begin{aligned}
w=f & (k)-k \cdot f^{\prime}(k) \\
& =(1-a) \cdot A k^{a} 3
\end{aligned}
$$

Where, the wages per worker are differences between national income per worker and rental income of capital per worker.

The share of capital in the creation of total output in the economy may be calculated using the following equation:

$$
R k / f(k)=a
$$

where: $R \cdot k$, the product between ренаталната cost of capital $R$ and capital per worker $k$ represents rental income per worker in the economy, $f(k)=y$, shows the output (income) per

\footnotetext{
${ }^{3}$ If we assume that total output is produced with only two factors of production (labor and capital), then the sum of wages and rental income of capital represents national income per worker $y=w+k \cdot R$, or, $w=y-k \cdot R$ Mathematical note: $y=f(k)=A k^{a}$ - output (income) per worker

$$
w=A k^{a}-a A k^{a-1} \cdot k=A k^{a}-a A k^{a}=(1-a) \cdot A k^{a} .
$$
}


worker, therefore the relationship between ренталниот income of capital and output (income) per worker shows the share of capital in the creation of total output in the economy ${ }^{4}$, and the equation:

$$
w / f(k)=(1-a)
$$

where: $w$, shows the ренталниот income from labor $^{5}$, or wages in the economy, and $f(k)=y$, shows the output (income) per worker, therefore the relationship between ренталниот income of labor (wages) and the output (income) per worker shows the share of labor in the creation of total output in the economy (in creation of gross domestic product GDP). ${ }^{6}$

Both coefficients can be used for the calculation of declining marginal returns to factors of production (labor and capital). Coefficient $a$, has less value, and refers to the yield on physical capital investment, and ratio $(1-a)$, has a bigger part in creating the total output ant it refers to contribution from growth of employment in economy.

The elasticity of substitution (e), is an important parameter for explaining the technology, and more for measuring the speed of falling yields. This parameter refers to the relative rate of change in factor shares $(K / L)$, which changes are the result of relative changes in the marginal rate of substitution, i.e., changes in relative factor prices $(w / r)$, influencing changes in factor shares.

The coefficient of elasticity can be shown using a mathematical equation:

$$
e=\frac{\frac{\Delta(K / L)}{(K / L)}}{\frac{\Delta\left(Y_{L} / Y_{K}\right)}{\left(Y_{L} / Y_{K}\right)}}=\frac{\frac{\Delta(K / L)}{(K / L)}}{\frac{\Delta(w / r)}{(w / r)}}
$$

\footnotetext{
${ }^{4}$ As we can see from the equation the share of capital in total output we note as $a$, and we said that in CobbDouglas function, $a=1 / 3$.

${ }^{5}$ Because the equation is in intensive form rental income from labor $w$ in intensive form we get when rental income from labor, $w L$ will divide with the number of workers, or: $w=w L / L$

${ }^{6}$ As we can see from the equation the share of labor in total output we note as $(1-a)$, analogous to the foregoing, if capital accounts for the third of total output creation, $a=1 / 3$, then the labor in creating the total output contributes with two-thirds, $(1-a)=2 / 3$.
} 
In Cobb-Douglas production function the elasticity is equal to one. It comes from the consistency of $a$ and $(1-a)$. Basically, the consistency of $a$ and $(1-a)$, produces constancy in their relationship

$$
\frac{1-a}{a}=\frac{Y_{L_{t}} L_{t} / Y_{t}}{Y_{K_{t}} K_{t} / Y_{t}}=\frac{Y_{L_{t}} L_{t}}{Y_{K_{t}} K_{t}}=\frac{w_{t} L_{t}}{r_{t} K_{t}}
$$

This can be true only if the relative changes in the relative factor prices $(w / r)$ are followed by the relative changes of factor shares $(K / L)$, or by the same logic in reverse.

Obviously, this is the case when the elasticity of substitution has a unit value. Mon realistic is to assume that the elasticity of substitution has a value less than one. In limited cases, such as the production function model of the Harrod-Domar, the value of the elasticity of substitution is zero, meaning that the effect of falling yield is current. On the other hand, when the elasticity of substitution is grater then one, then the effect of falling yields will be slower. In a limited case, when the elasticity is non-limits, which essentially is unrealistic, the effects of falling yields will tend to disappear. In both cases $(e>1$ и $e>1)$ the share of factors of productions (labor and capital) in creating the total output will not be constant, as is the case in Cobb-Douglas production function, in contrast (наспроти тоа), the participation factors change over time and depends on the elasticity of substitution. The concept of diminishing marginal product of factors previously elaborated briefly through the property of diminishing marginal product and so-called Inada condition.

\section{The Fisher Cobb-Douglas Paradox}

The economist Franklin Fisher in his article ${ }^{7}$, first documented a paradox in estimating substitution elasticities in Cobb-Douglas production function. Fisher found that, when aggregate factor shares were almost constant, the technology in Cobb-Douglas production function provided the best fit although no aggregate production function could be created form the underlying unit-level production function.

\footnotetext{
${ }^{7}$ The Fisher/Cobb-Douglas paradox, factors shares, and cointegration
} 
The Fisher Cobb-Douglas Paradox is "that an aggregate Cobb-Douglas production function will continue to work well if labor's share continues to be quite constant, although that rough constancy is not itself a consequence of the economy having a technology that is truly summarized by an aggregate Cobb-Douglas production function"

\section{Data and methodology}

We use annual data from 1899 to 1922 year, Cobb-Douglass production function for USA. These data were used by Paul Douglas and Charles Cobb in a study where they modeled the US growth from 1899 to $1922^{8}$. We use time series tests to see whether variables are cointegrated, which variables responds to shocks more quickly than others, descriptive statistics is given in next table.

\begin{tabular}{|cccccccc|}
\hline Variable & $\begin{array}{c}\text { Variable } \\
\text { description }\end{array}$ & Obs & Mean & Std.deviation & Max & Min \\
\hline loutput & $\begin{array}{c}\text { logarithm } \\
\text { of output }\end{array}$ & 26 & 2.246503 & 0.8047979 & 3.135494 & 0 \\
\hline lcapital & $\begin{array}{l}\text { logarithm } \\
\text { of capital }\end{array}$ & 26 & 2.348297 & 0.8295895 & 3.178054 & 0 \\
\hline llabour & $\begin{array}{c}\text { logarithm } \\
\text { of labour }\end{array}$ & 26 & 2.291471 & 0.7847897 & 3.091043 & 0 \\
\hline
\end{tabular}

Correlation matrix

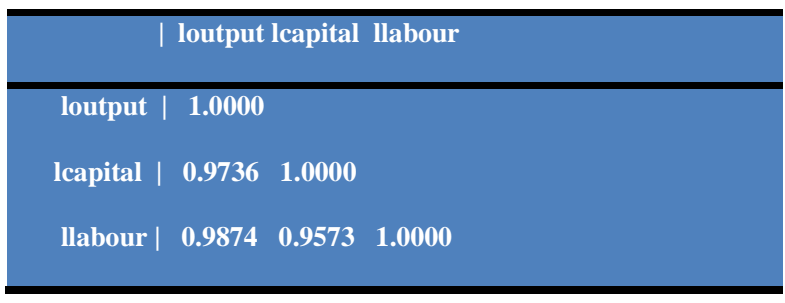

VECM models, johansens cointegration method and engle granger method will be applied.

\section{Graphical presentation of the variables}

First here we are going to plot the variables of interest. Variables of interest are loutput, lcapital and llabour.

\footnotetext{
${ }^{8}$ See Appendix 0 a note on the Cobb-Douglass PF
} 


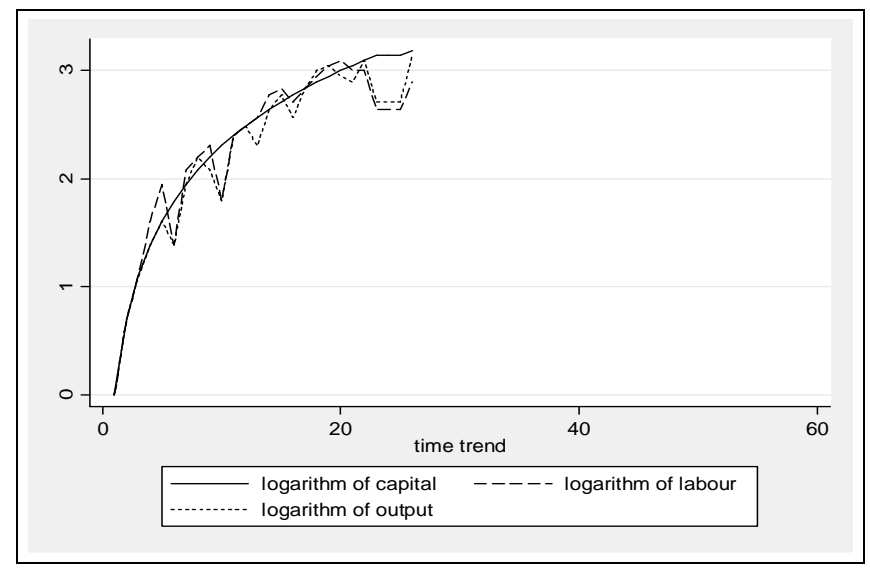

From the graph we can see that series are individually integrated (in the time series sense) but some linear combination of them has a lower order of integration, then the series are said to be cointegrated. A common example is where the individual series are first-order integrated (I(1)) but some (cointegrating) vector of coefficients exists to form a stationary linear combination of them. For an error-correction model we need non-stationary data and a longrun relationship (cointegration) between time-series e.g. moving magically together.

\section{$\underline{\text { CES }}$}

Cobb-Douglass production function in USA shows constant elasticity of substitution feature. More authors focus on capital as the factor and obtain aggregate estimates of $\sigma$ close to the Cobb-Douglas value of unity.Later, the Cointegration Model provides an elegant solution to the problem of estimating the substitution elasticity from data subject to short-run deviations from long-run values (Chirinko,Malick,1998). The equation of CES production function is, as it is generally accepted $Q=A\left[\delta K^{-\sigma}+(1-\delta) L^{-\sigma}\right]^{-1 / \rho}$, and about the parameters in the equation $(A>0 ; 0<\delta<1 ;-1<\rho \neq 0) K$ and L represent the two factors of production capital and labour and $A ; \delta$ Aand $\rho$ are the parameters in the equation. If we multiply the function with $\mathrm{J}$ each variable in the function we will show however that the function is homogenous with the degree one. Now we will multiply $\mathrm{K}$ and $\mathrm{L}$ with $\mathrm{j}$

$$
Q=A\left[\delta(j K)^{-\rho}+(1-\delta)(j L)^{\rho}\right]^{-1 / \rho}=A\left\{j^{-\rho}\left[\delta K^{-\rho}+(1-\delta) L^{-\rho}\right]\right\}^{-\rho}=\left(j^{-\rho}\right)^{-1 / \rho} Q=0 \sqrt{\left(\frac{1}{j^{\rho}}\right)} * Q=j Q
$$


So that proves that function is homogenous on first degree which implies constant returns to scale/Now about the inpust the optimal input ratio implies $\left(\frac{\bar{K}}{L}\right)=\left(\frac{\delta}{1-\delta}\right)^{1 /(1+\rho)}\left(\frac{p_{L}}{P_{K}}\right)^{1 /(1+\rho)}$ Now, if we replace $\left(\frac{\delta}{1-\delta}\right)^{1 /(1+\rho)}=c$; then, $\left(\frac{\bar{K}}{L}\right)=c\left(\frac{p_{L}}{P_{K}}\right)^{1 /(1+\rho)}$

Elasticity is ratio of marginal and average function, this input function ratio is a function of the two inputs prices Marginal function we find by definition like a ratio of the marginal changes of the two sides of the equation

$$
\begin{aligned}
& m \arg \text { inal_function }=\frac{d(\bar{K} / \bar{L})}{d\left(P_{L} / P_{K}\right)}=\frac{c}{1-\delta}\left(\frac{p_{L}}{P_{K}}\right)^{1 /(1+\rho)-1} \\
& \text { average _function }=\frac{\bar{K} / \bar{L}}{P_{L} / P_{K}}=c\left(\frac{p_{L}}{P_{K}}\right)^{1 /(1+\rho)-1}
\end{aligned}
$$

Elasticity of substitution is $\sigma=\frac{m \text { arg inal } \_ \text {function }}{\text { average }_{-} \text {fuction }}=\frac{1}{1+\rho}^{9}$

Least squares regression is presented in the following table ${ }^{10}$

\section{Dependent \\ variable is loutput}

\section{Variable}

lcapital

llabour

Constant

F-stat

$\mathrm{H}_{0}$ : model has no omitted variables

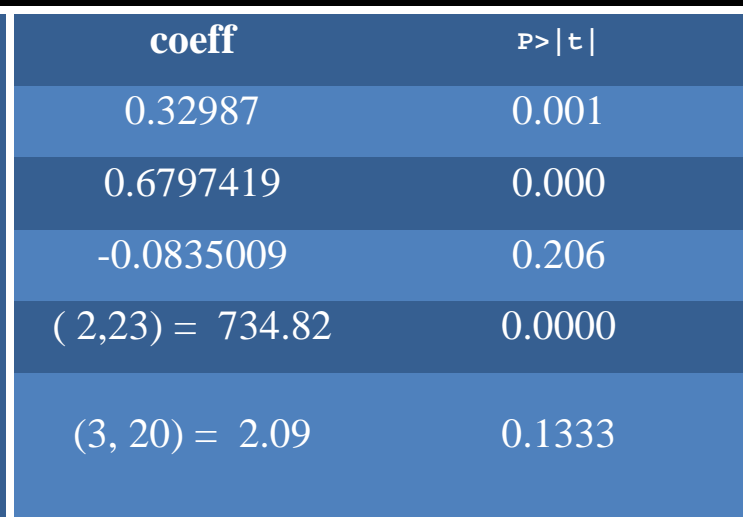

Here $\sigma=1$, constant elasticity of substitution .This production function is labor intensive since coefficient on log of labor is rounded on 0.68 and $\beta$ on capital is 0.32 . Data are from 1899 to 1922 , US economy back then was more labor intensive.

2 Chiang C.Alpha (1984), Fundamental Methods of Mathematical Economics McGraw-Hill International editions Chapter 12 pp 426-427

${ }^{10}$ See Appendix 1 OLS regression Cobb-Douglass function 


\section{Lag testing}

Here we are going to choose the number of lags that we are going to use later in Engle granger test and VECM, as well also cointegration tests.
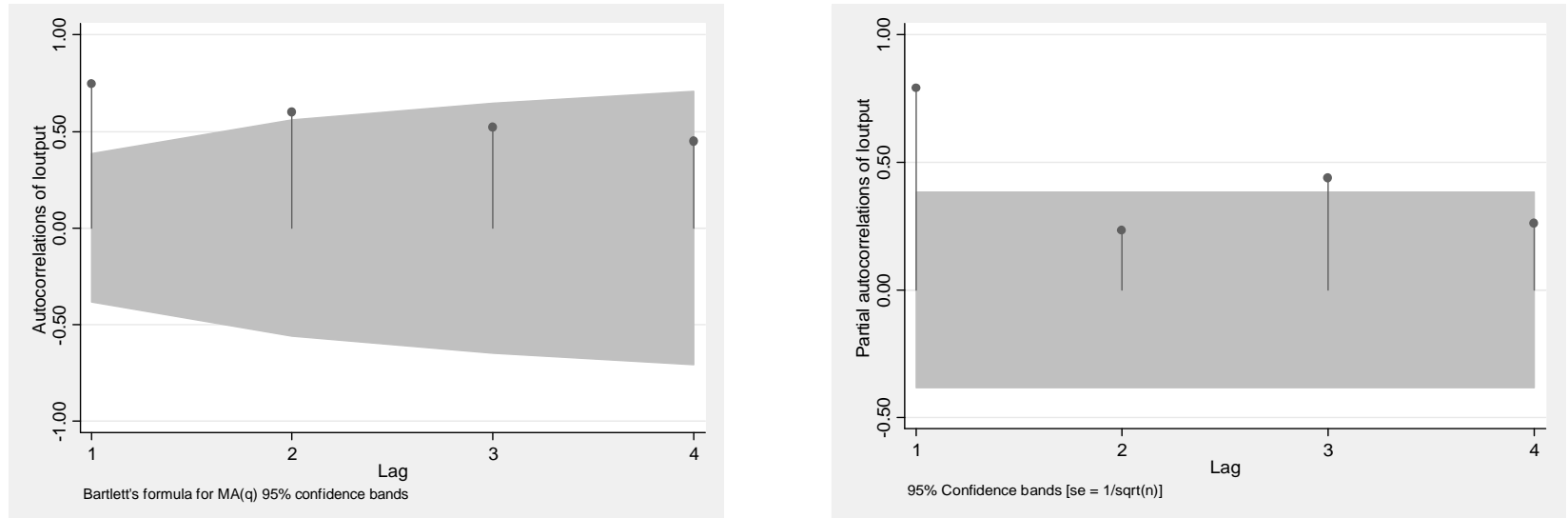

From the first graph we can see that at three and four lags autocorrelations of loutput are in the Bartlett's 95\% confidence bands. But partial correlation graph showed that only 4 lags are between $95 \%$ confidence bands. So we can choose between 3 or 4 lags depending on the testing procedure.

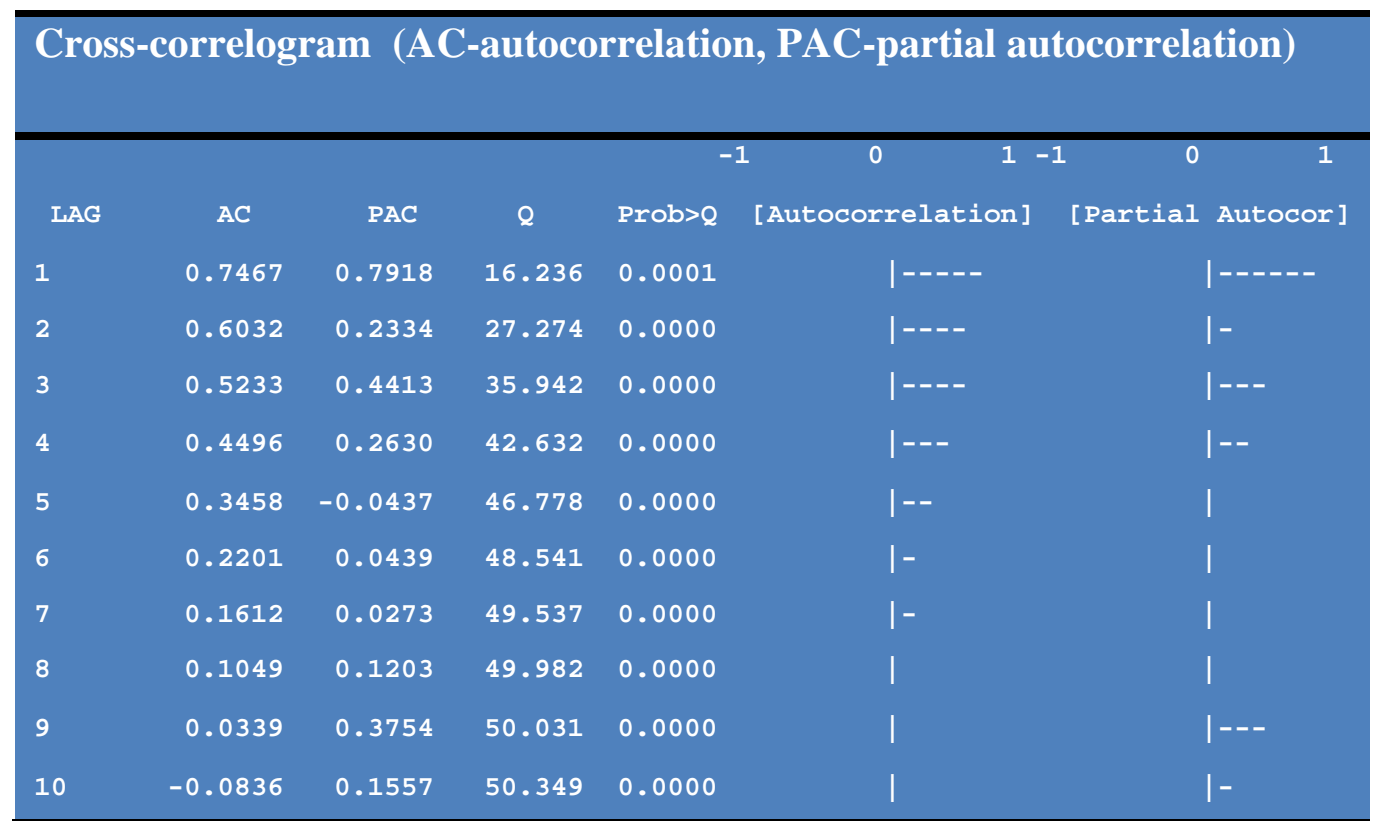

From the above cross-correlogram we can see that there exist positive autocorrelation in our data. Lag selection criteria involves:

Determination of $p$ such that

$\mathrm{A}_{i}=0$ for all $i>p$ in the VAR model. 
So we are finding the index of the most lagged value of $y_{t}$ that should contribute to the current value.

We may take one of two approaches

- $\quad$ Select based on LR Test

- $\quad$ Select based on Information Criteria

\section{Selection-order criteria}

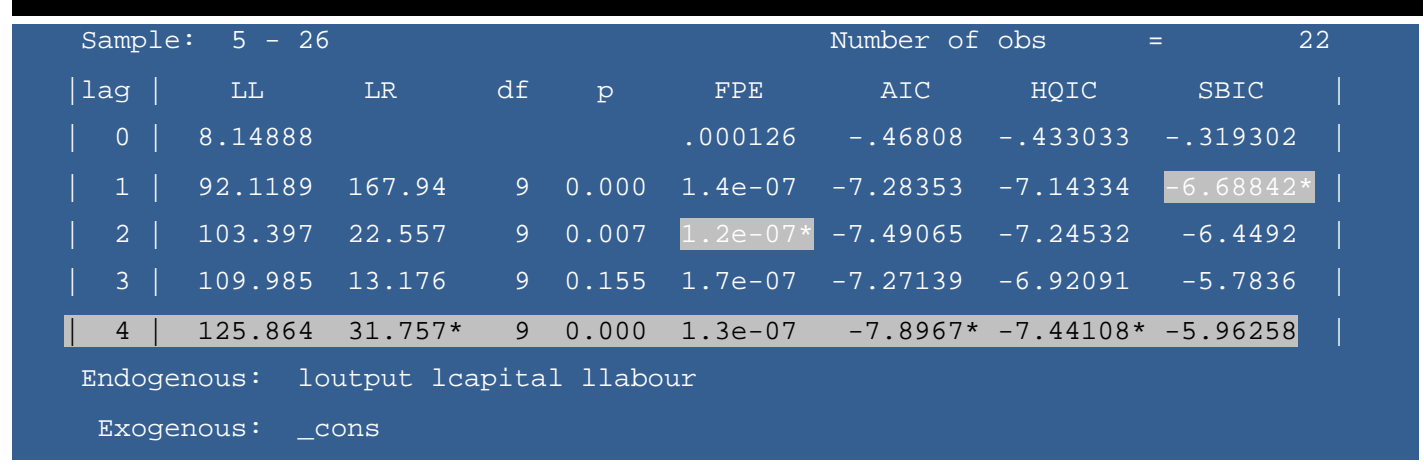

\section{Lagrange-multiplier test}

\begin{tabular}{|c|c|c|c|}
\hline | lag & chi2 & $d f$ & Prob $>$ chi2 \\
\hline 1 & 6.9192 & 9 & 0.64553 \\
\hline 2 & 14.8576 & 9 & 0.09492 \\
\hline 3 & 5.6123 & 9 & 0.77801 \\
\hline 4 & 4.3409 & 9 & 0.88757 \\
\hline
\end{tabular}

From the above Tables we choose asterisk option, and that is 4 lags. Also there is insufficient evidence to reject autocorrelation at lag order 4 .

\section{VAR stability checking}

Checking that a VAR(p) process is stable, that $\left|\mathrm{I}_{k}-\mathrm{A}_{1} z-\ldots-\mathrm{A}_{\mathrm{p}} z^{p}\right| \neq 0$ for complex $z,|z|$ $<1$. Is fairly straightforward. We merely find all the roots of $\left|\mathrm{I}_{k}-\mathrm{A}_{1} z-\ldots-\mathrm{A}_{\mathrm{p}} z^{p}\right|$, plugging in the estimates of the $\mathrm{A}_{i}$. From the tables below all eingevalues lie inside the unit circle, and VAR satisfies the stability condition. 


\section{Eigenvalue stability condition}

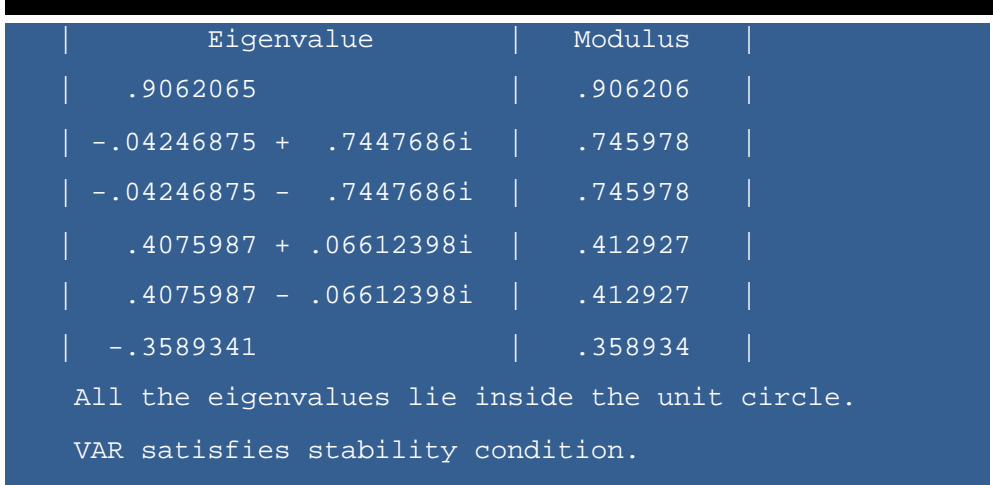

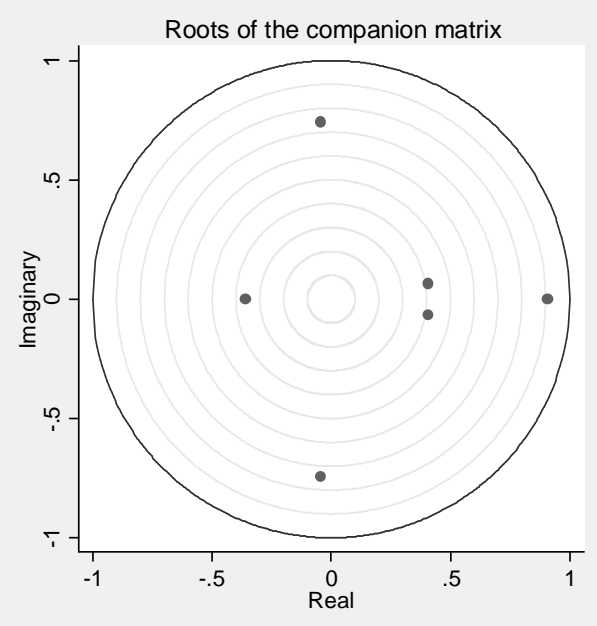

If we fit a VAR model and all of the assumptions are not met : 1)The inference we make using the model may be erroneous.2)Just like in linear regression, there are consequences (maybe dire) for using estimates from a flawed model.

\section{Unit root test on the errors}

\section{$\underline{\text { Augmented Dickey-Fuller test for unit root on errors }}$}

Dickey-Fuller test uses lags on the errors ${ }^{11}$.

\section{Test statistic $\quad-\mathbf{1 . 2 1 9}$}

$1 \%$ critical value

$5 \%$ critical value

$10 \%$ critical value

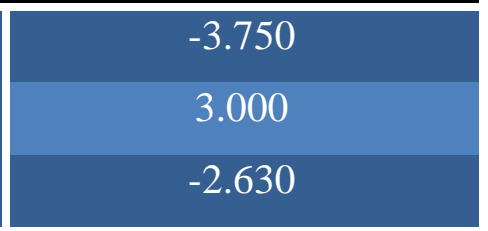

${ }^{11}$ See Appendix 2 unit root test for the residuals 


\section{Decision}

Non-stationarity, we

cannot reject the

existence of unit root

From the above table the decision is that we cannot reject the null hypothesis of existence of unit root. In the next table is given result from ADF(4 LAGS) test ${ }^{12}$.



\section{Plots of the residuals}

On the first graph are plotted residuals, and on the second graph are plotted residuals on the lag of the reisudals, and they seem to follow same pattern, i.e. are correlated (autocorrelation).
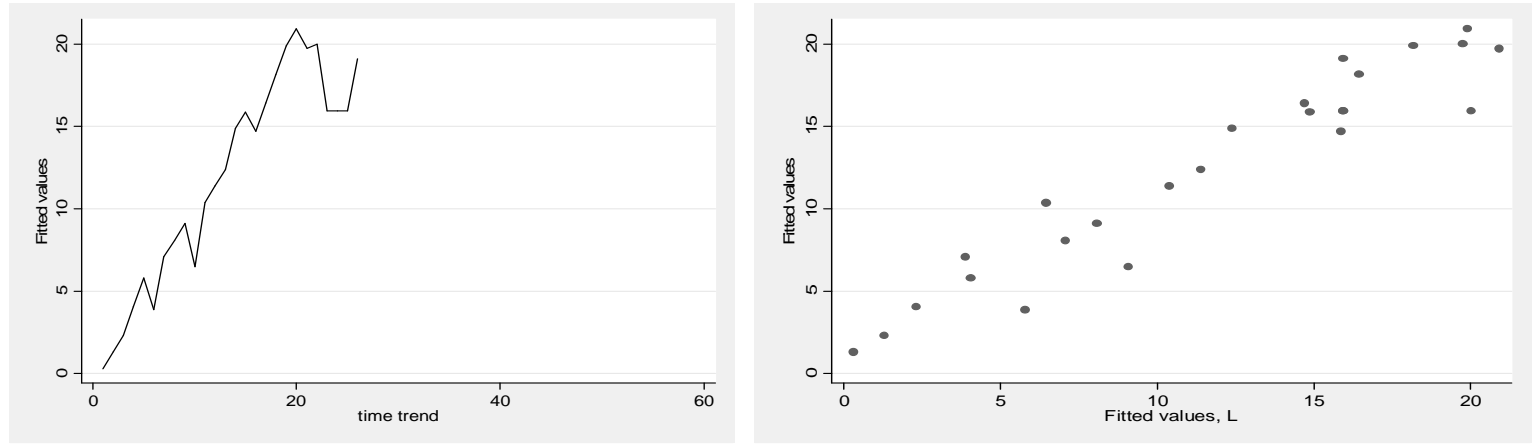

\section{Breusch Godfrey test on residuals}

This is a test for autocorrelation and in contradiction to white noise test that showed that residuals are not white noise, this test shows that autocorrelation is not a problem in our sample.

${ }^{12}$ Se Appendix 3 ADF test for the residuals 


\section{Autorrelation test on errors}

\begin{tabular}{c|ccc}
\multicolumn{3}{l}{ Breusch-Godfrey LM test for autocorrelation } & \\
$\operatorname{lags}(\mathrm{p})$ & chi2 & df & Prob > chi2 \\
4 & 2.269 & 4 & 0.6864 \\
& $\mathrm{H}_{0}$ : no serial correlation &
\end{tabular}

The null hypothesis here is no serial correlation if we reject it there is $68,64 \%$ chance of making type I error. In conclusion we have insufficient evidence to reject $\mathrm{H}_{0}$.

\begin{tabular}{|c|c|c|c|}
\hline $\begin{array}{l}\text { ADF test } \\
\text { for lcapital }\end{array}$ & & ADF test for llabour & \\
\hline $\begin{array}{l}\text { Test } \\
\text { statistic }\end{array}$ & -4.382 & Test statistic & 2.732 \\
\hline $\begin{array}{l}1 \% \text { critical } \\
\text { value }\end{array}$ & -3.750 & $1 \%$ critical value & -3.750 \\
\hline $\begin{array}{l}5 \% \text { critical } \\
\text { value }\end{array}$ & 3.000 & $5 \%$ critical value & 3.000 \\
\hline $\begin{array}{l}10 \% \text { critical } \\
\text { value }\end{array}$ & -2.630 & $10 \%$ critical value & -2.630 \\
\hline Decision & $\begin{array}{l}\text { stationarity, we can } \\
\text { reject the } \\
\text { existence of unit root }\end{array}$ & Decision & $\begin{array}{l}\text { Non-stationarity, we cannot reject the } \\
\text { existence of unit root except at } 10 \% \text {. }\end{array}$ \\
\hline
\end{tabular}

So from the above Table lcapital is stationary process, while llabour is stationary at $10 \%$.

\section{Jarque-Bera test for normality of the residuals}

Jarque -Bera matrix is presented below

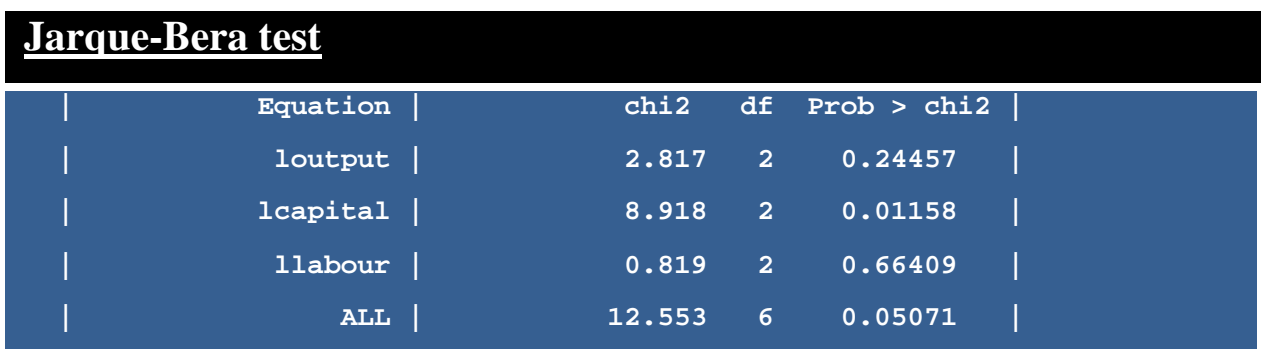

This result shows that non-normality is not a problem in the residuals. Probability of making type I error is high if we reject $\mathrm{H}_{0}$ of normality. 


\section{KPSS test}

Here KPSS test is performed up to 8 lags, here null hypothesis is that the chosen variable is trend stationary.


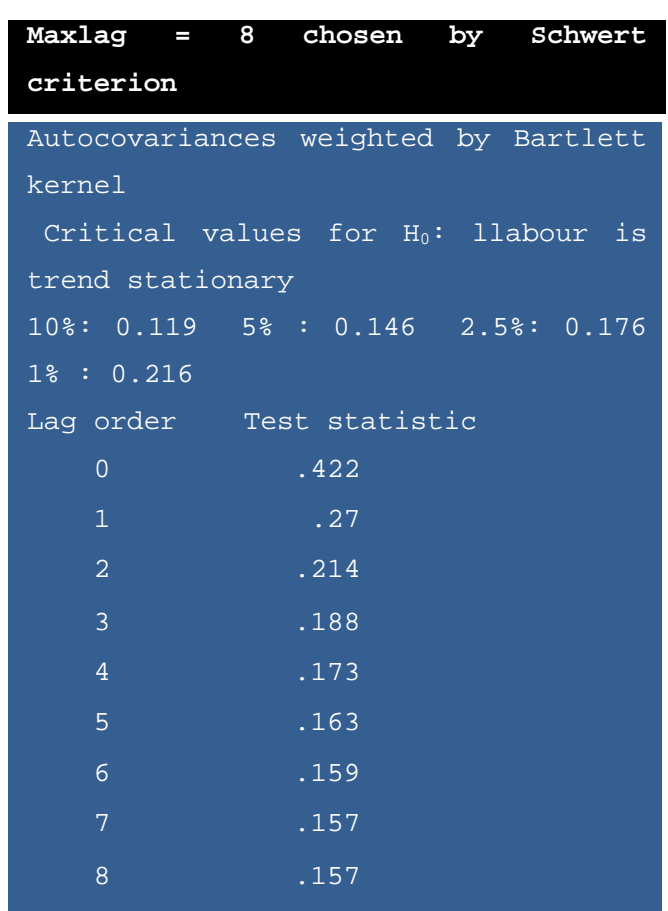

Note on KPSS test: KPSS test takes up to 8 lags null hypothesis is that variables are trend stationary. loutput is not trend stationary at 0 lags and at 1 lag i.e. has unit roots. This is true at 2 lags also. Even at three lags except at $1 \%$. We can reject the null hypothesis at all 8 lags. We can reject the null hypothesis of trend stationarity for lcapital and loutput variable also at 10 and $5 \%$ conventional levels of significance. 


\section{$\underline{\text { Vector rank test for co-integration (Johansen test) }}$}

Johansens test for cointegration results are given below in a table. This test is based on maximum likelihood estimation and two statistics: maximum eigenvalues and a tracestatistics. This is related to the rank of the matrix (let us ignore the theory behind it anyway). All we need to know, if the rank is zero, there is no cointegrating relationship. If the rank is one there is one, if it is two there are two and so on.

\section{Johansen tests for cointegration}

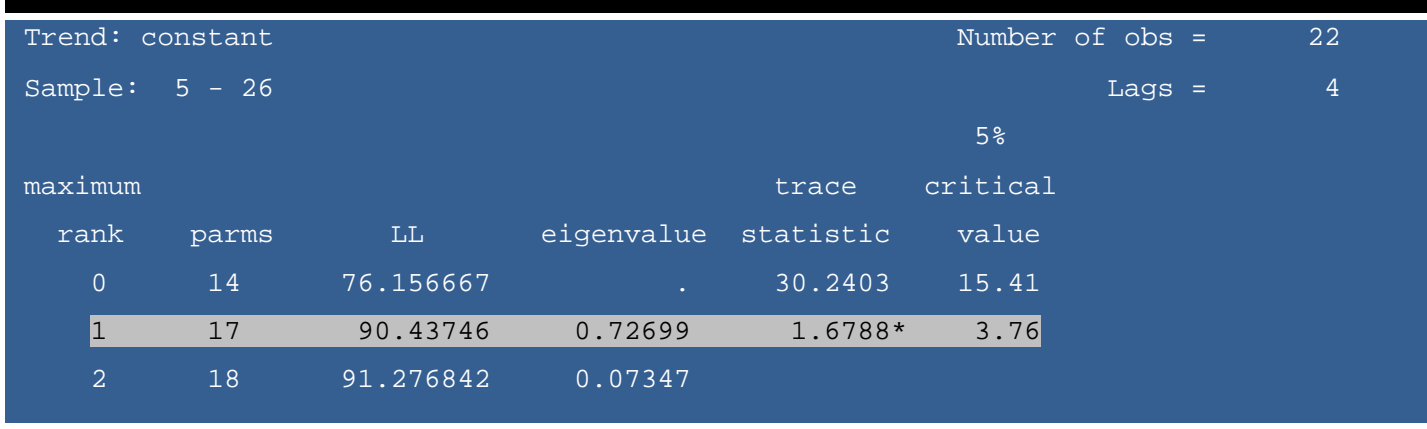

Maximum choice of rank is 1 , therefore these variables are co-integrated in order one I(1) variables. In the theory it is known that GNP is I(1) variable. However The Fisher/Cobb-

Douglas Paradox, holds at three lags there factor shares are $I(0)$ see from next table

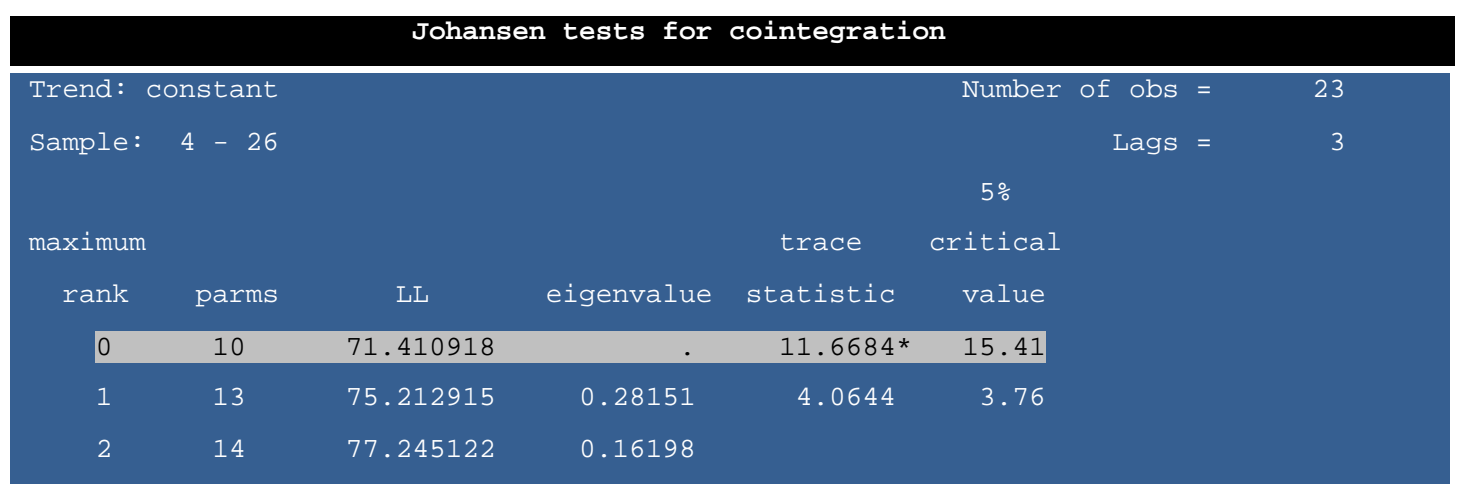




\section{Co-integrating equations}

In the next Table is given cointegrating equation.

\section{Cointegrating equations}

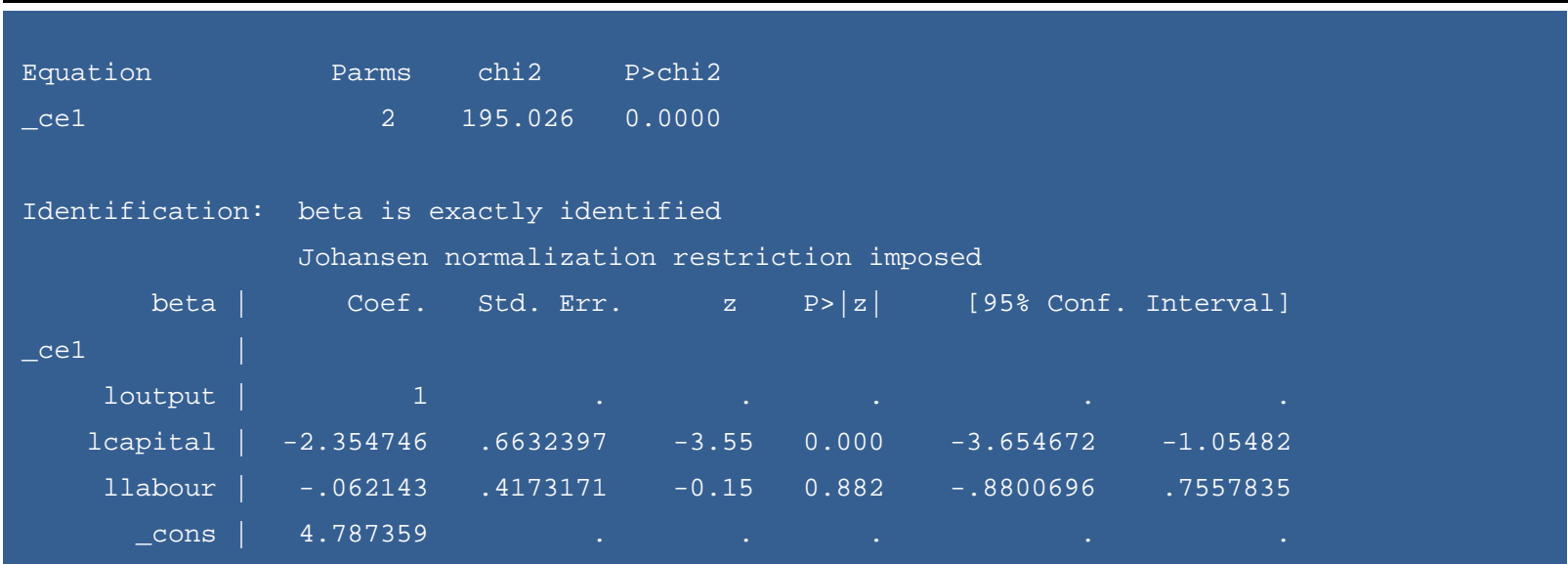

$y_{t} \sim \mathrm{I}(d)$ is cointegrated if there exists $k \times 1$ fixed vector $\beta \neq 0$ so $\beta^{\prime} y_{t}$ is integrated of order

$<d(\mathrm{I}(0)$ stable $)$.We say $y_{t} \sim \mathrm{CI}(d)$

\section{$\underline{\text { Adjustment parameters }}$}

If you use the option alpha you will get the short run adjustment parameters in your output too. Meaning which variable responds more, if there is change / shock in the system.

And we get




and it seems labour responds more / faster than loutput (log of GDP) and lcapital.

\section{$\underline{\text { VECM Stability }}$}

On the next plot we can see that VECM specification imposes 2 unit moduli.

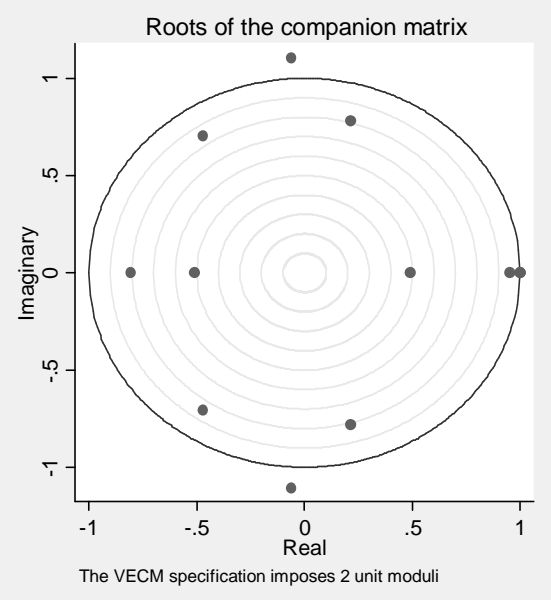

VECM stability graph showed that VECM specification is not stable, not all fo the eingevalues lie in the unit circle, i.e. two unit modulus $=1$.

Appendix 0 Note on the Cobb-Douglas model (1928)

The function that Cobb and Douglas used to model production was of the form:

$\mathrm{P}(\mathrm{L}, \mathrm{K})=\mathrm{bL}^{\alpha} \mathrm{K}^{\beta}$

where:

$\checkmark \mathrm{P}=$ total production (the monetary value of all goods produced in a year)

$\checkmark \mathrm{L}=$ labor input (the total number of person-hours worked in a year)

$\checkmark \mathrm{K}=$ capital input (the monetary worth of all machinery, equipment, and buildings)

$\checkmark \mathrm{b}=$ total factor productivity

$\checkmark \quad \alpha$ and $\beta$ are the output elasticities of labor and capital, respectively. These values are constants determined by available technology.

Further, if: $\alpha+\beta=1$, the production function has constant returns to scale. However, if $\alpha+\beta<1$, returns to scale are decreasing, and if $\alpha+\beta>1$, returns to scale are increasing. 
Production per unit labour assumes that

$\frac{\partial P}{\partial L}=\alpha \frac{P}{L}$, here $\alpha$ is constant. If $\mathrm{K}$ is constant than this will become ordinary partial differentiation.

$\frac{d P}{d L}=\alpha \frac{P}{L}$

This separable differential equation can be solved by re-arranging the terms and integrating both sides:

$\int \frac{1}{P} d P=\alpha \int \frac{1}{L} d L$ i.e. $\ln (\mathrm{P})=\alpha \ln (\mathrm{cL}) ; \ln (\mathrm{P})=\ln \left(\mathrm{cL}^{\alpha}\right)$

And finally,

$\mathrm{P}\left(\mathrm{L}, \mathrm{K}_{0}\right)=\mathrm{C}_{1}\left(\mathrm{~K}_{0}\right) \mathrm{L}^{\alpha}$

Similarly

$\frac{\partial P}{\partial K}=\alpha \frac{P}{K}$. Keeping $\mathrm{L}$ constant $\left(\mathrm{L}=\mathrm{L}_{0}\right)$, this differential equation can be solved to get:

$\mathrm{P}\left(\mathrm{L}_{0}, \mathrm{~K}\right)=\mathrm{C}_{2}\left(\mathrm{~L}_{0}\right) \mathrm{K}^{\beta}$ 


\section{Appendix 1 OLS regression Cobb-Douglass function}

\begin{tabular}{|c|c|c|c|c|c|c|c|}
\hline Source | & SS & $d f$ & \multicolumn{2}{|c|}{ MS } & & Number of obs $=$ & 26 \\
\hline Model & 15.9429852 & 2 & 7.97 & 49258 & & Prob $>F$ & $=0.0000$ \\
\hline Residual | & .249507886 & 23 & .010 & 48169 & & R-squared & $=0.9846$ \\
\hline Total | & 16.192493 & 25 & .64 & 99722 & & Root MSE & $=.10415$ \\
\hline loutput | & Coef. & Std. & Err. & t & $P>|t|$ & [95\% Conf. & Interval] \\
\hline lcapital | & .328917 & .0868 & 479 & 3.79 & 0.001 & .1492585 & .5085755 \\
\hline llabour & .6797419 & $.091 \xi$ & 056 & 7.40 & 0.000 & .4898276 & .8696563 \\
\hline _cons | & -.0835009 & .0642 & 125 & -1.30 & 0.206 & -.2163346 & .0493329 \\
\hline
\end{tabular}

\section{Appendix 2 Unit rot test for the residuals}

Number of obs $=21$

\begin{tabular}{|c|c|c|c|c|c|c|}
\hline \multirow{3}{*}{\multicolumn{2}{|c|}{$\begin{array}{c}\text { Test } \\
\text { Statistic }\end{array}$}} & \multicolumn{5}{|c|}{--------- Interpolated Dickey-Fuller } \\
\hline & & 1\% Critical & $5 \%$ & Critical & $10 \%$ & Critical \\
\hline & & Value & & Value & & Value \\
\hline$z(t)$ & -1.219 & -3.750 & & -3.000 & & -2.630 \\
\hline
\end{tabular}

Mackinnon approximate $\mathrm{p}$-value for $\mathrm{Z}(\mathrm{t})=0.6655$

Appendix 3 ADF test for the residuals 4 lags



Mackinnon approximate $p$-value for $\mathrm{Z}(\mathrm{t})=0.0271$ 
Refferences

1. Mackinnon,J., Davidson,R., (2004), Econometric Theory and Methods, Oxford University Press.

2. Chirinkko,R., Mallick,D., (1998), THE FISHER/COBB-DOUGLAS PARADOX, FACTOR

3. SHARES, AND COINTEGRATION, CESIFO WORKING PAPER NO. 1998.

4. Engle, Robert F., Granger, Clive W. J. (1987) "Co-integration and error correction: Representation,estimation and testing", Econometrica, 55(2), 251-276.

5. Gujarati, Damodar N.(2004), Basic Econometrics. New York: McGraw-Hill.

6. Tan, Hong, Bao(2008), Cobb-Douglas Production form, jamador.

7. Kaldor, Nicholas, "Capital Accumulation and Economic Growth," in Freidrich A. Lutz and Douglas C. Hague (eds.), The Theory of Capital (New York: St. Martin's Press, 1961), 177-222.

8. Chiang C.Alpha (1984),Fundamental Methods of Mathematical Economics McGraw-Hill International editions Chapter 12 pp 426-427

9. Helmut Lütkepohl (2005), New Introduction to Multiple Time Series Analysis, Springer series

10. Harris, R., Sollis,R., (2003), Applied Time Series Modelling and Forecasting, 